\title{
The Regulation of Anthocyanin Biosynthesis in Eustoma grandiflorum under Low Light Conditions
}

\author{
Saneyuki Kawabata, Yukie Kusuhara, Yuhua Li and Ryozo Sakiyama \\ Graduate School of Agricultural and Life Sciences, University of Tokyo, Yayoi, Bunkyo - ku, Tokyo 113-8657
}

\begin{abstract}
Summary
We investigated the influence of low light intensity on the pigmentation of petals in potted lisianthus [Eustoma grandiflorum (Raf.) Shinn.]. When whole plants were placed under 1,000 1x, the petals at anthesis had lighter petal than control flowers exposed to $10,000-15,000 \mathrm{~lx}$. Shading flower buds during the opening process had no effect on petal color intensity. However, shading the stem and leaf parts significantly reduced the intensity of petal color. When flower buds were detached with peduncles and placed in sucrose solutions, their petal color became more intense as the sucrose concentration was increased. There was a positive correlation between anthocyanin and soluble sugar content in the petals, regardless of light conditions. In detached flowers, the transcript levels of chalcone synthase, chalcone isomerase, and dihydroflavonol 4-reductase were enhanced as the sucrose concentration increased. These results suggest that low light intensity affects petal pigmentation through reduced photosynthesis in the leaves or stems, which, in turn, reduces the soluble sugar content of petals and leads to a repression of the genes that encode enzymes of anthocyanin biosynthetic pathway.
\end{abstract}

Key Words: anthocyanin biosynthesis, light, sugar, Eustoma grandiflorum.

\section{Introduction}

Light intensity is an important environmental factor, which affects the pigmentation of petals in many flowers. In lisianthus [Eustoma grandiflorum (Raf.) Shinn.], low light conditions during the flowering process markedly reduced the color intensity of the petals(Griesbach, 1992; Halevy and Kofranek, 1984). A 75 $\%$ decrease in light intensity was related to a $40 \%$ reduction in color intensity(Griesbach, 1992). The HPLC analysis showed that the total amount of flavonols and the composition of anthocyanins were not affected by light conditions, but the total anthocyanins were smaller in the flowers that opened under low light conditions(Griesbach, 1992).

Cut lisianthus flowers are usually marketed when an inflorescence consists of both open flowers and buds. While open flowers at harvest will keep their quality for about one week, buds will not develop well under room conditions. Some of these buds may open in a few days, but their petals are usually very thin and faded in color, making them unattractive.

The effect of light on anthocyanin biosynthesis has been studied in many plants. In general, the effect of light was attributed to a requirement for a photomorphogenic signal, mediated by photoreceptors (Mancinelli, 1983, 1985) or to a shortage of carbohydrates caused by restricted photosynthesis under low light conditions (Biran and Halevy, 1974). The requirement of carbohydrates was demonstrated in cut flowers of petunia (Weiss and Halevy, 1989, 1991) and Antirrhinum (Sang et al., 1991), by exogenously supplying sucrose to promote anthocyanin production. Carbohydrates can play two roles in anthocyanin biosynthesis: firstly, as a substrate for flavonoid biosynthesis via shikimic acid and phenylpropanoid pathways, and secondly as an inducer of genes involved in anthocyanin biosynthesis(Murray et al., 1994). Anthocyanin biosynthesis involves several enzymes, including phenylalanine ammonia-lyase (PAL), chalcone synthase (CHS), chalcone isomerase (CHI), and dihydroflavonol 4-reductase (DFR). Exogenous sucrose promoted the expression of CHS in petunia (Moalem-Beno et al., 1997), tea (Takeuchi et al., 1994), and CHS and DFR in ivy (Murray et al., 1994).

The objective of this study was to determine whether the effect of light on anthocyanin production was attributable to a direct effect on flower petals through photoreceptors or to an effect on leaves or stems through altered photosynthesis. In addition, we investigated the accumulation of transcripts for CHS, CHI, and DFR to examine whether the anthocyanin production is controlled by light conditions at the transcription level.

Received; March 16, 1998. Accepted; July 31, 1998. 


\section{Materials and Methods}

\section{Plant materials}

Seeds of Eustoma grandiflorum 'Royal Purple' (Takii Seed Co, Kyoto) were germinated in peat moss at $20^{\circ} \mathrm{C}$ under natural light. After 2 and 4 months, plants were transplanted to $5 \mathrm{~cm}$ and $10 \mathrm{~cm}$ pots, respectively, and grown at $25 / 20^{\circ} \mathrm{C}$ (day/night). Potting medium was a $4: 6$ mixture of peatmoss and 'Kureha Engei Baido' (Kureha), a heat-processed granulated soil with $\mathbf{N}: \mathbf{P}: \mathrm{K}=$ $0.4: 1.4: 0.4 \mathrm{~g} \cdot \mathrm{kg}^{-1}$.

Developmental stages of lisianthus flowers are defined as follows: stage 1, the growth rate of flower petals is slow; stage 2, (3-5 days before anthesis), flowers enlarge but without pigmentation; stage $3,(2-1$ day before anthesis), the growth of the petals accelerates and pigmentation starts from the edge of the petals; and stage 4 , anthesis, when the petals are fully expanded and pigmented. Before the experiments, all flowers at stages 3 and 4 on the inflorescence were removed and only those in stage 2 were used.

\section{Experiment 1: Effects of light intensity on petal pigmentation}

Potted plants were transferred to a growth room at 23 ${ }^{\circ} \mathrm{C}$ and a $14-\mathrm{hr}$ photoperiod; light $(15,000 \mathrm{~lx})$ was supplied by metal halide lamps (Yoko lamp, Toshiba). Six plants were placed in a frame, the sides of which were covered with 2 layers of black cheese cloth and topped with aluminum foil. The light intensity inside the frame was set at 1,000 $\mathrm{lx}$ by adjusting the distance from the lamps to the plants. Another six plants used for control were not shaded. At anthesis, the fresh weight of flowers, color intensity, and anthocyanin content of the petals were measured.

\section{Experiment 2: Effects of shading plant parts on pigmentation}

Potted plants were transferred to a growth room kept at $25{ }^{\circ} \mathrm{C}, 14-\mathrm{h}$ photoperiod, $10,000 \mathrm{~lx}$, and divided into three groups. In group 1, whole plants were shaded as in Experiment 1. In group 2, flowers at the end of stage 2 were selected and their parts were enclosed in a box covered with aluminum foil on top and 2 layers of black cheese cloth on the sides and bottom. In group 3, the stems and leaves were shaded with 2 layers of black cheese cloth along the entire stem length, and with aluminum foil just below the calyx. For each group, a comparable group of unshaded plants was prepared as control. The light intensity around shaded parts of the plants in each treatment was $1,000 \mathrm{~lx}$. At anthesis, fresh weight of the flowers and color intensity of the petals from 6 to 13 plants were measured.

\section{Experiment 3: Effects of light and sucrose on petal pigmentation in detached flowers}

Flowers at the end of stage 2 with peduncles of about $5 \mathrm{~cm}$ long were detached from the plants using a sharp blade. Groups of 4 to 7 detached flowers were placed in vials containing $0,0.125,0.25$, or $0.50 \mathrm{M}$ sucrose solutions and shaded (700 1,000 lx); a comparable group of flowers was placed in sucrose solutions and exposed to 15,000 $\mathrm{lx}$ in the growth room as in Experiment 1. After the flowers were sampled at anthesis and their fresh weight of the flowers and color intensity of the petals were measured, the petals were frozen in liquid nitrogen, and stored at $-80{ }^{\circ} \mathrm{C}$ until used for northern blot analysis. Another group of detached flowers was placed in vials containing $0.25 \mathrm{M}$ sucrose solution and shaded (700 1,000 lx) or kept in sucrose solutions but under 15,000 lx. At anthesis, 11 and 6 flowers were sampled and analyzed, respectively, for anthocyanin and soluble sugar contents.

\section{Measurements of color intensity}

Pigmentation of flower petals was evaluated using scores between 0 and 255. Graphical gray scale images of petals were scanned with a scanner (Epson GT6000), and the average color intensity of 0.5 to $2 \mathrm{~cm}^{2}$ petal was calculated using 'NIH Image'.

For anthocyanin analysis, $1 \mathrm{~cm}^{2}$ sections were excised from petals and steeped in $1 \mathrm{ml}$ of acidic methanol containing $1 \% \mathrm{HCl}$ at $4{ }^{\circ} \mathrm{C}$ for 12 to 24 hours. After diluting the solution to a known volume with the acidic methanol, its absorbance at $510 \mathrm{~nm}$ was measured. The optical density of the original $1 \mathrm{ml}$ solution was calculated as the relative anthocyanin content.

\section{Carbohydrate analysis}

The samples were freeze-dried, ground into a fine powder in a mortar and pestle and extracted with $80 \%$ ethanol at $80^{\circ} \mathrm{C}$ for 1.5 hour. The extract was filtered through a Whatmann $\mathrm{GF} / \mathrm{F}$ filter, dried in a rotary evaporator at $45{ }^{\circ} \mathrm{C}$; the residue was dissolved in $2 \mathrm{ml}$ distilled water and the solution was centrifuged at $15,000 \mathrm{x} g$ for $10 \mathrm{~min}$. The supernatant was loaded on a Cosmosil $5 \mathrm{NH}_{2}$ (Nakarai) column and eluted with $80 \%$ acetonitrile-water $(80: 20)$ at the rate of $1 \mathrm{ml} \cdot \mathrm{min}^{-1}$ at $33{ }^{\circ} \mathrm{C}$. The eluates were analyzed for carbohydrates using a Shimadzu 10A HPLC system equipped with a refractive index detector (RI-2, Japan Analytical Industry).

\section{Preparation of total RNA}

Petal tissue was ground into a fine powder under liquid nitrogen and suspended in an extraction buffer $(100 \mathrm{mM}$ Tris- $\mathrm{HCl}, \mathrm{pH} 8.5,200 \mathrm{mM} \mathrm{NaCl}, 10 \mathrm{mM}$ EDTA, $1 \% \mathrm{w} / \mathrm{v}$ SDS). The suspension was extracted twice with an equal volume of phenol-chloroform $(1: 1$ $\mathrm{v} / \mathrm{v}$ ) and once with chloroform, followed by propanol 
Table 1. Nucleotide sequences of the specific primers used for amplifying chalcone synthase (CHS), chalcone isomerase (CHI), and dihydroflavonol 4 - reductase (DFR) genes.

\begin{tabular}{|c|c|c|}
\hline Gene & Fragment length (bp) & Sequences of primers \\
\hline \multirow[t]{2}{*}{ CHS } & 164 & 5'-AARGARTGGGGNCARCCNAA-3' \\
\hline & & 5'-GTNCCNCCNGCRAARCANCC-3' \\
\hline \multirow[t]{2}{*}{$\mathrm{CHI}$} & 194 & 5'-TTYCTYGNYGGKGCNGG-3' \\
\hline & & 5'-GTRAAYTTYTCRAANGGNCC--3' \\
\hline \multirow[t]{2}{*}{ DFR } & 284 & 5'-ACMGTNTGYGTCACNGG-3' \\
\hline & & 5'-TTDATNAYTTCRTTCTCAGG - ${ }^{\prime}$ \\
\hline
\end{tabular}

N: A, C, G, T; D: A, G, T; R: A, G; Y: C, T; M: A, C; K: G, T.

precipitation. The sample was subjected to selective $\mathrm{LiCl}$ precipitation. After ethanol precipitation, the pellet containing RNAs was dissolved in sterile water.

\section{Isolation of partial cDNAs for CHS, CHI, and DFR}

For the isolation of cDNAs for CHS, CHI, and DFR assays, RNA was extracted from partially pigmented petals of lisianthus. The total RNA was subjected to reverse transcription followed by polymerase chain reaction (PCR), using RNA PCR kit (Perkin Elmer Cetus). The degenerate primers used are listed in Table 1. The amplified fragments were separated on agarose gels by electrophoresis and recovered from the gels by using Gene Clean II (Bio101). The purified fragments were cloned into pCRII (Invitrogene) or pBluescriptIISK+ (Stratagene) for sequence analysis and preparation of hybridization probes. The sequences of the clones were determined on A.L.F. DNA sequencer (Pharmacia) by a dye primer method using T7 DNA polymerase according to the manufacturer's instruction.

\section{Northern blot analysis}

mRNA was purified from the total RNA by using Oligotex-dT30 Super (Takara). One $\mu \mathrm{g}$ of mRNA was separated on $1.2 \%$ agarose gels, containing formaldehyde (Maniatis et al., 1982). Northern blot analyses were performed on nylon membrane (MagnaGraph, Funakoshi) with probes labeled with digoxygenin (Boehringer Mannheim) by PCR labeling. Hybridizations and signal detections were performed by using DIG Nucleic Acid Detection kit (Boehringer Mannheim), according to the manufacturer's instructions.

\section{Results}

\section{Experiment 1: Effects of light intensity on petal pigmentation}

Pigmentation of lisianthus flowers starts 2 to 3 days before anthesis and is completed at anthesis. While investigating the effects of light on pigmentation, we found that plants with flowers at stage 2 exposed to $15,000 \mathrm{~lx}$ or $1,000 \mathrm{~lx}$ took 2 to 3 days and 3 to 6 days for the flowers to open, respectively. The pigmentation, whether measured by color intensity or anthocyanin
Table 2. Effects of light intensity on flower fresh weight and petal pigmentation in $E$. grandiflorum.

\begin{tabular}{lccc}
\hline \hline Conditon & $\begin{array}{c}\text { Fresh weight } \\
(\mathrm{g})\end{array}$ & $\begin{array}{c}\text { Color } \\
\text { intensity }^{2}\end{array}$ & $\begin{array}{c}\text { Anthocyanin content } \\
\left(\mathrm{A}_{510} \cdot \mathrm{cm}^{-2} \text { petal }\right)\end{array}$ \\
\hline Control & 2.14 & 143 & 1.15 \\
Shaded & $1.90^{\text {n.s. }}$ & $97^{* * *}$ & $0.47^{* *}$
\end{tabular}

Potted plants with flowers at stage 2 ( 3 - 5 days before anthesis; without pigmentation) were placed at $15,000 \mathrm{~lx}$ (control) or at $1,000 \mathrm{~lx}$ (shaded) until the flowers opened.

${ }^{z}$ Images converted to gray scale, $\mathrm{O}$ : white, 255: black.

n.s. , **, ${ }^{* * *}$ Nonsignificant or significant at $P=0.01$ or 0.001 by $\mathrm{t}$ - test, respectively. $\mathrm{n}=6$.

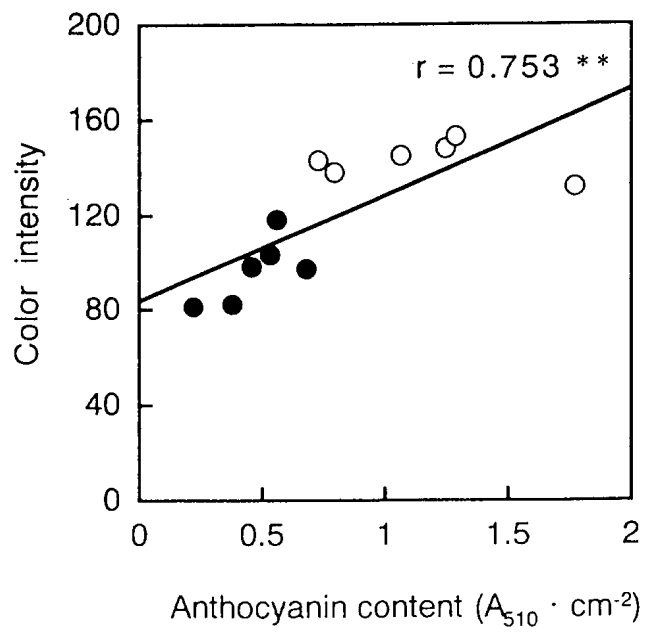

Fig. 1. A scatter plot showing a correlation between anthocyanin content and petal color intensity measured with a scanner in petals of lisianthus flowers which opened under $1,0001 \times(\bigcirc)$ or $15,0001 \times(\bigcirc)$. Graphical gray scale images were scanned and the average tone of the images was expressed as scores between 0 (white) and 255(black). ** Significant at $\mathrm{P}=0.01$ by $\mathrm{F}-$ test.

content, was lower in shaded flowers than it was in unshaded ones (Table 2).

In this study, color intensity was measured with a scanner because it gave a good estimate (gray scale scores) of the petal color as unpigmented petals were very pale yellow to greenish white. Hence, the color intensity measured by a scanner was positively corre- 
Table 3. Effects of shading whole plants, flowers, or stem and leaf parts on flower fresh weight and petal pigmentation in E. grandiflorum.

\begin{tabular}{lccccc}
\hline \hline \multirow{2}{*}{ Shaded part of the plants } & \multicolumn{2}{c}{ Fresh weight $(\mathrm{g})$} & & \multicolumn{2}{c}{ Color intensity $^{z}$} \\
\cline { 2 - 3 } \cline { 5 - 6 } & Control & Shaded & & Control & Shaded \\
\hline Whole plants & 1.70 & $1.41^{*}$ & & 136 & $96^{* * *}$ \\
Flowers & 1.55 & $1.45^{\text {n.s. }}$ & & 133 & $129^{\text {n.s. }}$ \\
Stems and leaves & 1.55 & $1.35^{* *}$ & & 132 & $87^{* * *}$ \\
\hline
\end{tabular}

Potted plants with flowers at stage 2 were placed at $10,000 \mathrm{~lx}$ with or without shading until the flowers opened.

Light intensity at shaded parts was $1,000 \mathrm{~lx}$.

${ }^{z}$ Images converted to gray scale, 0 : white, 255 : black.

n.s. $,{ }^{*},{ }^{* *},{ }^{* * *}$ Nonsignificant or significant at $\mathrm{P}=0.05,0.01$, or 0.001 by $\mathrm{t}$-test, respectively. $\mathrm{n}=6$ to 13 .

lated ( $\mathrm{r}=0.753)$ with anthocyanin content (Fig.1).

\section{Experiment 2: Effects of shading plant parts on pigmentation}

When flower, leaf and stem parts, or whole plants were shaded to see how plants respond to low light intensity with respect to pigmentation of petals, the results varied. When only flower parts were shaded, the flowers showed the same degree of growth and petal pigmentation as did unshaded flowers (Table 3), whereas when stems and leaves were shaded, growth and petal pigmentation of flowers were reduced. These results indicate that low light intensity reduced the petal pigmentation through an effect on stems or leaves but not through that on flowers.

\section{Experiment 3: Effects of light and sucrose on petal pigmentation in detached flowers}

Experiment with potted plants suggested that under low light intensity, an insufficient supply of photosynthates to flowers was responsible for the reduced level of anthocyanins.

To test.this hypothesis, unopened flowers with their peduncles at the end of stage 2 were detached and immediately placed in various concentrations of sucrose and kept under 15,000 or $1,000 \mathrm{~lx}$. These detached flowers opened 3 to 6 days after the beginning of the incubation. As sucrose concentration was increased from 0 to $0.5 \mathrm{M}$, the flower color became darker at both 15,000 lx and 1,000 lx (Table 4). Analysis of variance showed that the effects of sucrose and shading on color intensity were significant at $0.1 \%$ and $1 \%$ level, respec-

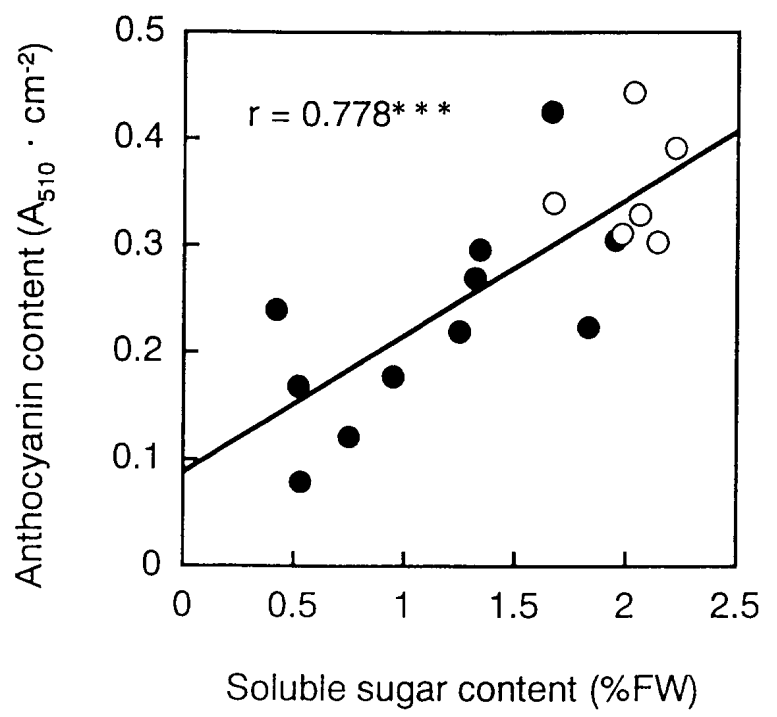

Fig. 2. A scatter plot showing a correlation between anthocyanin and soluble sugar contents in petals of lisianthus flowers with peduncles placed in $0.25 \mathrm{M}$ sucrose solution at $1,000 \mathrm{~lx}(\bigcirc)$ or $15,000 \mathrm{~lx}(\bigcirc)$ for 4 to 6 days. *** Significant at $\mathrm{P}=0.001$ by $\mathrm{F}-$ test.

Table. 4. Effects of exogenous sucrose on flower fresh weight and petal pigmentation in E. grandiflorum.

\begin{tabular}{cccccc}
\hline \hline \multirow{2}{*}{$\begin{array}{c}\text { Sucrose Concentration } \\
(\mathrm{M})\end{array}$} & \multicolumn{2}{c}{ Fresh weight $(\mathrm{g})$} & & \multicolumn{2}{c}{ Color intensity $^{\mathrm{z}}$} \\
\cline { 2 - 3 } \cline { 5 - 6 } & Control & Shaded & & Control & Shaded \\
\hline 0 & $1.46 \mathrm{a}$ & $1.46 \mathrm{a}$ & & $73 \mathrm{c}$ & $69 \mathrm{c}^{\mathrm{y}}$ \\
0.125 & $1.38 \mathrm{a}$ & $1.39 \mathrm{a}$ & & $104 \mathrm{~b}$ & $79 \mathrm{c}$ \\
0.25 & $1.53 \mathrm{a}$ & $1.53 \mathrm{a}$ & & $120 \mathrm{ab}$ & $108 \mathrm{~b}$ \\
0.5 & $1.67 \mathrm{a}$ & $1.65 \mathrm{a}$ & & $131 \mathrm{a}$ & $120 \mathrm{ab}$ \\
\hline
\end{tabular}

Flowers at stage 2 were datached from plants and placed in sucrose solutions of various concentrations at $15,000 \mathrm{~lx}$ (control) or $1,000 \mathrm{~lx}$ (shaded) until the flowers opened.

${ }^{z}$ Images converted to gray scale, $\mathrm{O}$ : white, 255 : black.

${ }^{\mathrm{y}}$ Means followed by the same letters within control and shaded columns are not significantly different at $P=0.05$ by Duncan's new multiple range test. $n=4$ to 7 . 
CHS

E. grandiflorum AAGGAGTGGG GCCAACCCAA GTCTAAGATC ACCCATCTAG TCTTCTGCAC CACTAGTGGT

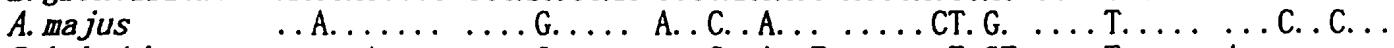

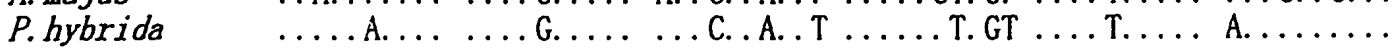

$\begin{array}{llllll}70 & 80 & 90 & 100 & 110 & 120\end{array}$

E. grandiflorum GTGGACATGC CTGGTGCTGA CTATCAGCTC ACCAAGCTCC TGGGCCTTC GTCCTCGGTT A. majus $\quad$.C..........G..A. . T..................... CC. T. . . . C P. hybrida $\quad \ldots \ldots \ldots \ldots$...GTG................... .T. . G... TC. A...C

$\begin{array}{rrrrr}130 & 140 & 150 & 160 & 164\end{array}$

E. grandiflorum AAGCGGTTCA TGATGTACCA ACAGGGTTGC TTTGCGGGTG GGAC

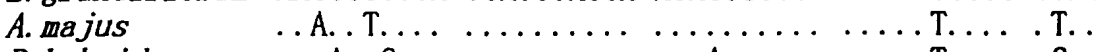

P.hybrida $\quad$.................................

$\mathrm{CHI}$

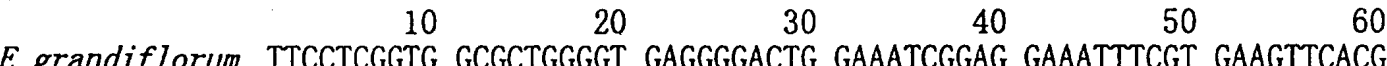
A.majus $\quad \ldots . \ldots \ldots$. T. . A...........GG.T ..G...CA. . .G..G...A. C......T

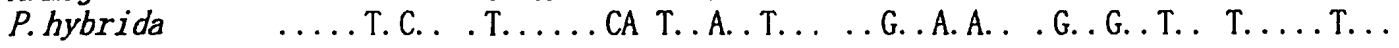

$\begin{array}{llllll}70 & 80 & 90 & 100 & 110 & 120\end{array}$

E. grandiflorum GCGATCGGTA TTTACTTGGA CGAGACTGCA ATTCCGTGGC TCGCCGGCAA GTGGAAAGGC

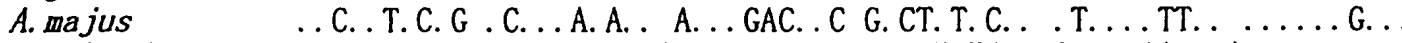
P. hybrida …A...G.G. TC.A.. A...G..T ....T.TT. .G...AA.. A........ $\begin{array}{llllll}130 & 140 & 150 & 160 & 170 & 180\end{array}$

E. grandiflorum AAGACGGCCG AGGAGTTGGC TGATTCCGTT GACTTCTTCG CCGATATCAT CACTGGTCCA

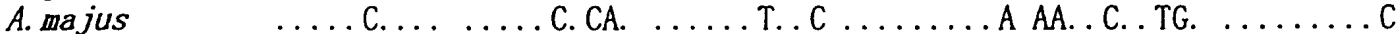

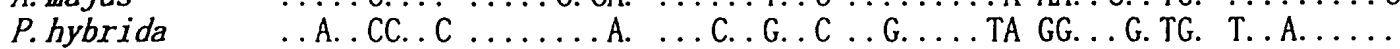
$190 \quad 194$

E. grandiflorum TTTGAGAAGT TCAC

A. majus

P. hybrida

…........ . T.

DFR

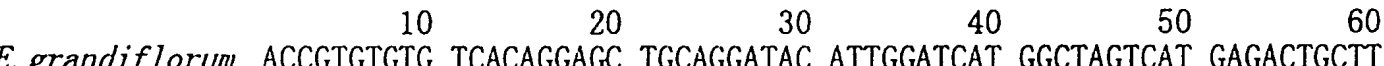

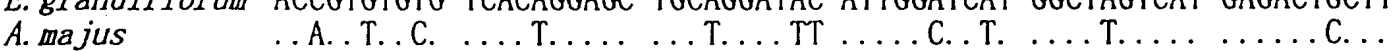
P. hybrida $\quad \ldots \ldots$ A............... T. .A..C................ $\begin{array}{llllll}70 & 80 & 90 & 100 & 110 & 120\end{array}$ E. grandiflorum GAACGCGGCT ACACTGTTCG TGCCACTGTC CGTGATCCTG GTGATGTAAA GAAGGTGAAG

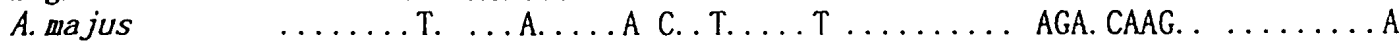

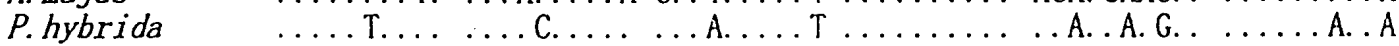
$130 \quad 140 \quad 150 \quad 160 \quad 170 \quad 180$ E. grandiflorum CATCTATTTG AGTTGCCAAA GGCCAGCACA AATTTGACAG TGTTAAAAGC AGACTTGATT A. MAJUS $\quad$....GC.G. . AC. ....... . TGAT. . . . C. . A... ...G.... G. .....CA

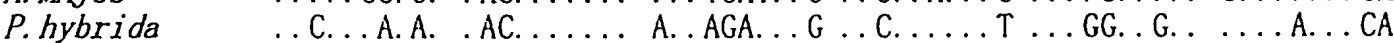
$190 \quad 200 \quad 210 \quad 220 \quad 230 \quad 240$

E. grandiflorum GAAGAAGGAA GCTTTGATGA AGCCATTCAA GGCTGTCATG GAGTGTTTCA TATGGCTACA

A.majus $\quad$ T. ............ . G. ..............................

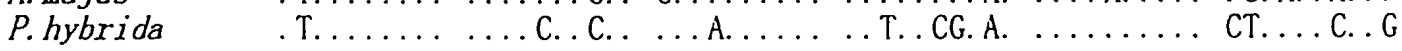

$250 \quad 260 \quad 270 \quad 280 \quad 284$

E. grandiflorum CCTATGGAAT TCGAATCCAA AGACCCTGAG AATGAAATGA TCAA

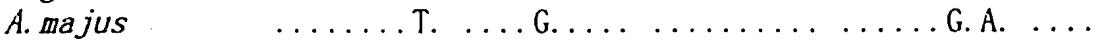

P.hybrida T........ T..T...GT G..T...............

Fig. 3. Nucleotide sequences of CHS, CHI, and DFR cDNA fragments isolated from partially pigmented petals of $E$. grandiflorum. The sequences are compared with Antirrhinum majus (CHS: Sommer and Saedler, 1986; CHI: Martin et al., 1991; DFR: Beld et al., 1989 ) and Petunia hybrida (CHS: Koes et al., 1989b; CHI: van Tunen et al., 1988; DFR: Beld et al., 1989). Dots denote identity to the $E$. grandiflorum sequences. 

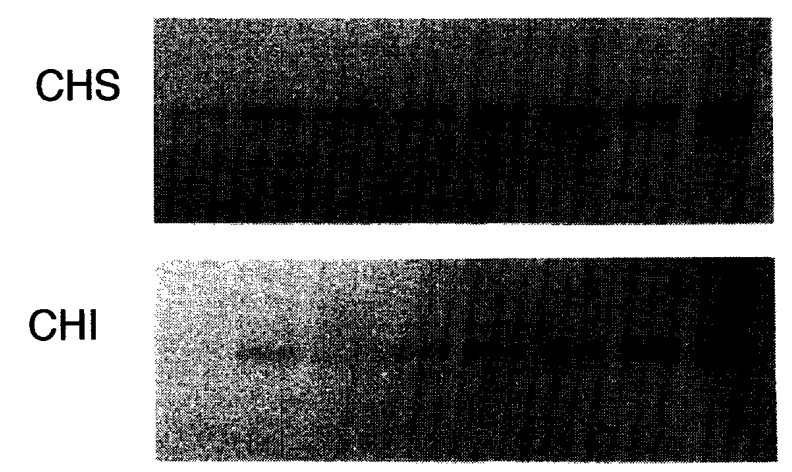

DFR
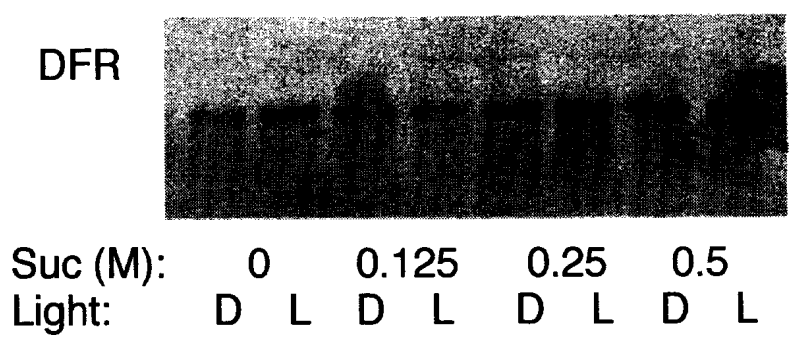

Fig. 4. Gel plates (northern-blot analysis) of CHS, CHI, and DFR mRNAs derived from detached flowers of $E$. grandiflorum. Flowers with peduncles were placed in 0 , $0.125,0.25$, or $0.5 \mathrm{M}$ sucrose solution (Suc) under 1,000 $\operatorname{lx}(\mathrm{D})$ or $15,000 \mathrm{~lx}(\mathrm{~L})$ for 3 to 6 days until the anthesis. The cDNA clone used as a probe in hybridization is indicated at the left.

tively. When the detached flowers were incubated in 0.5 $M$ sucrose solutions at high light intensity, the petal color was as dark as that of the intact flowers that opened under high light intensity.

Unlike attached flowers, low light intensity significantly decreased flower color in detached flowers (Table 4). However, carbohydrate analysis showed that contents of total soluble sugars in the petals were lower in unshaded flowers; hence, a positive correlation was found between the sucrose and anthocyanins contents (Fig. 2), suggesting that the effect of light on petal pigmentation in detached flowers was through reduced sucrose uptake.

\section{Transcriptional control of anthocyanin synthesis}

Using degenerate primers listed in Table 1, partial cDNAs for CHS,CHI, and DFR were successfully amplified. The amplified fragments were cloned into plasmids and identified by determining the nucleotide sequences (Fig. 3). Using the isolated clones as probes, northern blot analysis was performed for detached flowers in Experiment 3.

At both $15,000 \mathrm{~lx}$ and $1,000 \mathrm{~lx}$, the levels of the transcripts of CHS, CHI, and DFR increased as the concentration of sucrose was elevated in the culture solution (Fig.4); they were also higher in plants exposed to high light intensity.

\section{Discussion}

The light condition affects anthocyanin content in petals through photoreceptor mediated reaction or photosynthesis which provides necessary carbohydrates for anthocyanin biosynthesis. In studies on 'Masquerade' roses, the effects of light on pigmentation were attributed to the effects on petals (Shisa and Takano, 1964), but on leaves on 'Baccara' roses(Biran and Halvey, 1974). In petunia (Moscovici et al., 1996), pigmentation was reduced by shading flowers or a leaf, suggesting that photoreceptors in the petals as well as the carbohydrate supply participated in the control of pigmentation. In our study of lisianthus (Table 3), shading entire plants had no effects on pigmentation of petals, whereas shading leaves and stems markedly reduced it. The results indicate that reduced pigmentation under low light intensity occurs through an effect on the leaves or stems but not through that on petals.

The experiments on detached flowers demonstrated a promotive effect of sucrose and high light intensity on pigmentation. The light effect was attributable to the higher content of soluble sugars in the petals rather than to the light intensity. The degree of pigmentation was positively correlated with the soluble sugar content independent of light conditions. Therefore, the degree of pigmentation seems mainly dependent on the soluble sugar content in the petals, and that restricted export of photosynthates from the leaves or stems under low light conditions is most responsible for the reduced pigmentation in lisianthus.

With detached flowers, irradiation with high light intensity significantly increased the soluble sugar content in the petals (Fig. 2). That the uptake of sucrose by detached corolla of petunia was enhanced by high light intensity was reported by Moscovici et al. (1996). In Antirrhinum, optimum sucrose concentration in the vase solution for improving the pigmentation was lower for flowers placed at high light intensity(Sang et al., 1991), indicating that the uptake of sucrose was more efficient at high light intensity. Regarding these results, it appears that the sink activity of rose flowers was promoted by irradiation of shoots (Mor and Halevy, 1980). Lang and Thorpe (1986) and Pickard et al. (1979) proposed that carbohydrate translocation depends on water potential gradient between the source and the sink organs. Similarly, Lee (1989) and Swanson et al. (1976) postulated that transpiration in the sink organ was the driving force behind carbohydrate mass flow into the sink. Because high light intensity probably enhances the transpiration from the irradiated tissues (Swanson et al., 1976), while simultaneously increasing soluble sugar content, both processes enhanced transpiration-driven sucrose accumulation by the flowers.

Moscovici et al. (1996) reported that corolla growth and anthocyanin biosynthesis in petunia were in response to light on green leaves or sepals. They proposed 
that an unknown metabolite produced in leaves or stems exposed to light was transmitted to flowers and participated in the regulation of anthocyanin biosynthesis. In our study, however, flowers separated from leaves and stems became equally pigmented as attached flowers under high light conditions as long as the flowers were supplied with $0.5 \mathrm{M}$ sucrose. Therefore, the carbohydrate supply seems sufficient for pigmentation and that other metabolites may not be involved in pigment formation in lisianthus. Moreover, shading of intact flowers with sepals had no effect on pigmentation, suggesting that light perceived by the sepals was not involved in this process.

CHS, CHI, and DFR cDNA clones which we isolated to investigate the expression patterns in relation to anthocyanin production revealed that the genes were all dependent on the concentration of exogenous sucrose. The transcript levels for these enzymes were also correlated with anthocyanin accumulation in petunia (van Tunen et al., 1988; Beld et al., 1989; Koes et al., 1989a) and Antirrhinum (Martin et al., 1991; Jackson et al., 1992).

Of these three enzymes, CHS and CHI are involved in biosynthesis of both anthocyanin and flavonol, whereas DFR is specifically involved in anthocyanin biosynthesis. CHS and CHI provide dihydroflavonol, the common substrate for both DFR and flavanol synthase(FLS), which catalyze the production of flavonol. Griesbach (1992) showed that low light conditions affected anthocyanin accumulation without any influence on flavonol accumulation; this indicates that the production of dihydroflavonol through $\mathrm{CHS}$ and $\mathrm{CHI}$ under low light conditions was sufficient for FLS activity. In lisianthus, anthocyanin accumulation in relation to flower development was correlated with the transcript level of DFR , but not with PAL, CHS, and CHI transcripts(Davies et al.,1993). In this regard, the activity of DFR or other enzymes in the later steps of the pathway, instead of CHS or CHI, may play a key role in the control of anthocyanin biosynthesis in lisianthus.

In conclusion, our results suggest that the pale color of petals in flowers under low light conditions is caused by the restricted supply of carbohydrates from leaves or stems, which in turn lowers soluble sugar content in the petals. This reduced soluble sugar content caused the repression of genes in the anthocyanin biosynthetic pathway. Hence, petal pigmentation of lisianthus flowers under low light conditions can be improved either by increasing carbohydrate content in the leaves or stems before harvest, or by genetically transforming the plants so that genes responsible for anthocyanin biosynthesis become independent of soluble sugar content in the petals.

\section{Literature Cited}

Beld, M., C. Martin, H. Huits, A. R. Stuitje and A. G. M. Gerats. 1989. Flavonoid synthesis in Petunia hybrida: partial characterization of dihydroflanovol-4-reductase genes. Plant. Mol. Biol. 13: 491-502.

Biran, I. and A. H. Halevy. 1974. Effects of varying light intensities and temperature treatments applied to whole plants, or locally to leaves or flower buds, on growth and pigmentation of 'Baccara' roses. Physiol. Plant. 31: $175-179$.

Davies, K. M., J. M. Bradley, K. E. Schwinn, K. R. Markham and E. Podivinsky. 1993. Flavonoid biosynthesis in flower petals of five lines of lisianthus (Eustoma grandiflorum Grise.). Plant Sci. 95: 67-77.

Griesbach, R. J. 1992. Correlation of $\mathrm{pH}$ and light intensity on flower color in potted Eustoma grandiflorum Grise. HortScience 27: 817-818.

Halevy, A. H. and A. M. Kofranek. 1984. Evaluation of lisianthus as a new flower crop. HortScience 19: $845^{-}$ 847.

Jackson, D., K. Roberts and C. Martin. 1992. Temporal and spacial control of expression of anthocyanin biosynthetic genes in developing flowers of Antirrhinum majus. Plant J. 2: 425-434.

Koes, R. E., C. E. Spelt and J. N. M. Mol. 1989a. The chalcone synthase multigene family of Petunia hybrida (V30): differential, light-regulated expression during flower development and UV light induction. Plant Mol. Biol. 12: 213-225.

Koes, R. E., C. E. Spelt, P. J. van den Elzen and J. N. Mol. 1989b. Cloning and molecular characterization of the chalcone synthase multigene family of Petunia hybrida. Gene 81: 245-257.

Lang, A. and M. R. Thorpe. 1986. Water potential, translocation and assimilate partitioning. J. Exp. Bot. 37: 495503.

Lee, D.R. 1989. Vasculature of the abscission zone of tomato fruit: implications for transport. Can. J. Bot. 67: 1898-1902.

Mancinelli, A. L. 1983. The photoregulation of anthocyanin synthesis. p.640-661. In: W. Shropshire Jr. and H. Mohr (eds.), Encyclopedia of plant physiology, New series, Vol. 16B, Springer-Verlag, Berlin.

Mancinelli, A. L. 1985. Light-dependent anthocyanin synthesis: a model system for the study of plant photomorphogenesis. Bot. Rev. 51: 107-157.

Maniatis, T., E. F. Fritsch and J. Sambrook. 1982. Molecular cloning: a laboratory manual. Cold Spring Harbor Laboratory, Cold Spring Harbor, N.Y.

Martin, C., A. Prescott, S. Mackay, J. Bartlett and E. Vrijlandt. 1991. Control of anthocyanin biosynthesis in flowers of Antirrhinum majus. Plant J. 1: 37-49.

Moalem-Beno, D., G. Tamari, Y. Leitner-Dagan, A. Borochov and D. Weiss. 1997. Sugar-dependent gibberellin-induced chalcone synthase gene expression in petunia corollas. Plant Physiol. 113: 419-424.

Mor, Y. and A. H. Halevy. 1980. Promotion of sink activity of developing rose shoots by light. Plant Physiol. 66: 990-995.

Moscovici, S., D. Moalem-Beno and D. Weiss. 1996. Leaf- 
mediated light responses in petunia flowers. Plant Physiol. 110: 1275-1282.

Murray, J. R., A. G. Smith and W. P. Hackett. 1994. Differential dihydroflavonol reductase transcription and anthocyanin pigmentation in the juvenile and mature phases of ivy (Hedera helix L.). Planta 194: 102-109.

Pickard, W. F., P. E. H. Minchin and J. H. Troughton. 1979. Real time studies of carbon-11 translocation in moonflower. III. Further experiments on the effects of a nitrogen atmosphere, water stress, and chilling; and a qualitative theory of stem translocation. J. Exp. Bot. 30: 307-318.

Sang, C. K., Y. S. Choi and H. Y. Kim. 1991. Effects of light, sucrose and growth regulators on the coloration of cut snapdragon flower: I. Effects of light intensity and sucrose. J. Korea. Soc. Hort. Sci. 32: 130-136.

Shisa, M. and T. Takano. 1964. Effect of temperature and light on the coloration of rose flowers. J. Japan. Soc. Hort. Sci. 33: 140-146.

Sommer, H. and H. Saedler.1986. Structure of the chalcone synthase gene of Antirrhinum majus. J. Mol. Gen. Genet. 202: $429-434$.
Swanson, C. A., J. Hoddinott and J. W. Sij. 1976. The effect of selected sink leaf parameters on translocation rates. p. 347-356. In: J. F. Wardlaw and J. B. Passioura (eds.). Transport and transfer processes in plants. Academic Press, New York.

Takeuchi, A., S. Matsumoto and M. Hayatsu. 1994. Chalcone synthase from Camellia sinensis: isolation of the cDNAs and the organ-specific and sugar-responsive expression of the genes. Plant Cell Physiol. 35: 10111018.

van Tunen, A. J., R. E. Koes, C. E. Spelt, A. R. van der Krol, A. R. Stuitje and J. N. M. Mol.1988. Cloning of the two chalcone flavanone isomerase genes from Petunia hybrida: coordinate, light-regulated and differential expression of flavonoid genes. EMBO J. 7: 1257-1263.

Weiss, D. and A. H. Halevy. 1989. Stamens and gibberellin in the regulation of corolla pigmentation and growth in Petunia hybrida. Planta 179: 89-96

Weiss, D. and A. H. Halevy. 1991. The role of light reactions in the regulation of anthocyanin synthesis in Petunia corollas. Physiol. Plant. 81: 127-133.

\title{
低照度環境におけるトルコギキョウのアントシアニン合成の調節 \\ 河鯺実之・楠原紀江・李 玉花・崎山亮三 \\ 東京大学大学院農学生命科学研究科 113-8657 東京都文京区弥生
}

\begin{abstract}
摘 要
低照度条件が鉢植えトルコギキョウの花弁着色に及ぼす影 響について調査した，植物体全体を遮光すると $(1,000 \mathrm{~lx})$, 遮 光環境下で開花した花の花色が薄くなった．開花時に花のみ を遮光した場合には花色に影響は見られなかったが，茥葉部 のみを遮光すると, 植物体全体の遮光時と同じく花色が薄く なった．花を花柄部で切り離しスクロース溶液に浸漬させた 状態で開花させると，スクロース濃度の上昇とともに花弁の 色は濃くなった．さらに，花弁の糖濃度とアントシアニン濃

度との間には，光条件に関係なく正の相関がみられた．これ らの花では, スクロース濃度の上昇にともなってカルコン合 成醭素, カルコン異性化䤃素, ジヒドロフラボノール 4-還元 醉素の遗伝子の発現量が促進された，以上の結果より，低照 度環境下でトルコギキョウ花弁の着色が低下するのは, 茎葉 部における光合成の低下にともなう花弁中の可溶性糖含量の 低下によって，アントシアニン合成経路上の䣼素の発現が抑 制されるためであることが示唆された。
\end{abstract}

